\title{
Non-conventional learning on sustainable development: achieving the SDGs
}

Walter Leal Filho $0^{1,2^{*}}$ (1)

\begin{abstract}
Learning has been identified as a critical tool for the achievement of sustainable development. But whereas the literature predominantly focuses on the use of classroom-based teaching methods and approaches, there is a perceived need to shed some light on the potential role which can be played by non-conventional learning. Based on the relevance of addressing this need, this commentary describes the role of non-conventional learning methods in supporting the achievement of the UN Sustainable Development Goals. In particular, it discusses the contribution of nonconventional teaching as a catalyst for a more active participation of learners, and also shows some of the trade-offs.
\end{abstract}

Keywords: Sustainability, Learning, Methods, SDGs

\section{Introduction: learning and sustainable development}

Learning has been identified as a critical tool for the achievement of sustainable development as a whole, and to the UN Sustainable Development Goals (SDGs) in particular [13].

Indeed, various United Nations agencies (e.g. UNESCO, UNEP, UNDP) have highlighted that learning should go beyond the primary, secondary and tertiary phase, to ensure that all age groups and cultural groups are able to be educated. This has been incorporated into the UN's Sustainable Development Goal 4 (SDG4) which focuses on providing equitable education and promoting lifelong learning [15]. But learning is also an important feature in all other SGs, and is closely associated with them. For instance, learning can help to reduce poverty (SDG1), reduce malnutrition (SDG2) and may yield positive health benefits (SD3), to name a few examples.

Learning on a sustainable development context-also known as education for sustainable development-fosters people's awareness about their connections with their

\footnotetext{
${ }^{*}$ Correspondence: w.leal@mmu.ac.uk

${ }^{1}$ European School of Sustainability Science and Research, Hamburg

University of Applied Sciences, Hamburg, Germany

Full list of author information is available at the end of the article
}

environment and how they influence it. It also opens up the minds of people about the means they can deploy in order to live more sustainably and-if they so wish-take action to meet the SDGs [11]. More specifically, learning about sustainable development may mobilise society by targeting specific learning content and outcomes, and by linking them. It allows people to learn about the need for sustainability and to make informed decisions about how their actions influence the environment, the economy and society, reminding about the need to respect and take into account others. This, in turn assists in fostering a more favourable world for the present and future generations [4].

The process of learning on sustainable development has shown to significantly contribute to the development of new skills, tools and concepts that are utilised in abolishing unsustainable practices. Furthermore, it aids in building resilience to a variety of social problems. Learning also helps in all aspects of everyday life, offering skills which may help a person to become more confident, become more competitive and even strengthen relationships, as well as fostering the ability to handle conflicts inherent to the relations between persons and their environment.

Sustainability learning is also multi-faceted. It allows knowledge to be transferred about personal experiences, 
values and opinions which promotes social cohesion and inclusivity [1]. Whereas it is clear that learning plays an important role in the success of sustainable development [3], it is useful to look at the contribution of specific and non-conventional learning environments.

\section{The usefulness of non-conventional learning on sustainable development}

There are various elements which speak for the use of non-conventional learning, especially when perceived under a sustainable development context $[5,6]$, a trend also advocated by UNESCO [13].

The first one is that it be used as a basis for discussing and exchanging meaningful arguments, with the possibilities of accommodating various types of answers, out of a "yes-no" context.

In addition, non-conventional learning is especially useful in terms of acquisition of insights, and the fostering of a wide range of competences, also being able to flexibly use information and discussions based on empirical studies, without the usual constraints posed by tight teaching schedules.

Moreover, the deployment of informal approaches may help to decentralise teaching, from being teachercentred to learners focused. Here, the influence of teachers may be as catalysts of learning, using their skills in a way that may meet the needs of the learners in a flexible manner. For instance, by providing advice on appropriate methods, by giving hints on which procedures may need to be followed, or by simply encouraging learners to experiment.

But despite the advantages, there are some trade-offs to be considered. For instance, the role of teachers, which changes from "instructor" to "moderator" may mean that not all learners can easily cope with the task of selforganising their own learning. This might be a problem, especially for young learners, who may not be able to, or feel comfortable with, working independently.

Also, in order to yield the expected results, non-conventional learning cannot be limited to trivial topics on simply reproduce conventional teaching formats, and this requires more planning time. Moreover, in order to provide an insightful overview of how the learners progress, specific evaluation formats are needed. This is also a sensitive issue, since the standard measures of performances do not always take into account the assessment of the extent to which some skills such as creative thinking or problem-solving, were developed.

In any case, it is important to reiterate that the approaches of non-conventional and conventional teaching do not necessarily need to be antagonistic to each other. Indeed, they can be mutually complementary.

\section{Sustainability learning in non-conventional environments}

There are various types of non-conventional or non-classroom-based learning environments, and a wide range of means to promote knowledge on matters related to sustainable development outside formal settings. Indeed, the importance of learning in different environments is significant, since it caters for flexible ways to transmit information and discuss contents, also helps in the transfer of knowledge. Among the many types of non-conventional learning environments on a sustainable development context, mention can be made to four of them: lifelong learning, transformative learning, and learning based on traditional knowledge. Due to their importance, they will be described in turn.

Lifelong learning has been described as a developmental tool that can be used as an effective tool to support learning on, through and about the environment [7], can provide a strong framework for the achievement of the SDGs. It can be used as an accessory for stakeholder engagement, international partnerships, social equity and lastly to alleviate poverty. The process of lifelong learning goes before and well beyond the school phase, which allows people to continually learn and adapt their knowledge accordingly [14]. This is especially important in developing countries, where learners spend far less time at school, than their counterparts in industrialised nations.

This power of transformative learning is also substantial, especially in conditioning the mindsets of humans to promote sustainability in specific sectors as varied as:

a. economic aspects,

b. social matters and

c. environmental affairs. [9]

Truly transformative leaning is also able to play a transformative role itself, i.e. to provide insights into knowledge for action that enable actors to be and remain capable of acting in the transformation process.

This is not to say that conventional teaching and learning methods are not transformative. However, traditional learning is often subject based, and the connections between subjects are not always that clear. In order to be truly transformative, learning needs to break the barriers posed by individual disciplines, and take into account the need to offer learners an opportunity to constantly adjust their thinking, and based on new information, change their opinions and perspectives in a truly autonomous way.

Experience-based learning is a didactic method used in school and university teaching. This can be done in group activities or as individual initiatives 


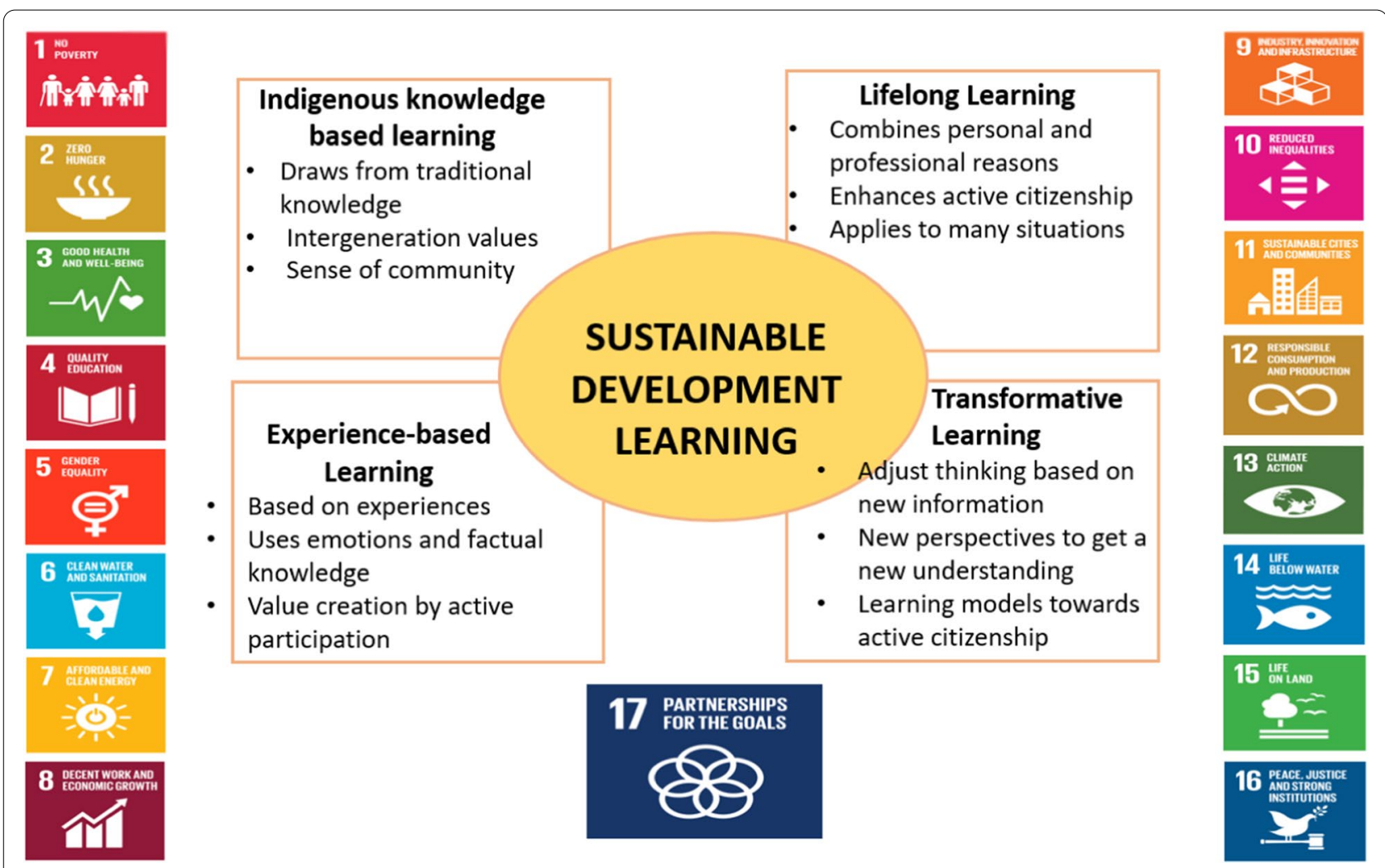

Fig. 1 Varieties of non-traditional learning methods on sustainable development

[10]. Practical and interaction-oriented exercises are designed in such a way that they recall past experiences and enable new experiences. These are then comprehensively reflected upon, and be combined with theory or existing factual knowledge, depending on the needs and learning objectives, and across subjects [2]. Implicit knowledge is thus transformed into explicit knowledge and a space for an integration of emotions and cognitive factual knowledge takes place. The nature of this process means that participants are likely to remember their experiences for long periods of time.

The use of indigenous knowledge-based learning is also an item which deserves attention. Unfortunately, the literature on this modality of learning in a sustainable development context still has many gaps. Indigenous knowledge-based learning is, in many cultures and settings, more effective-and often more beneficial-than learning in a traditional setting. This is because it entails themes and issues which are not only cross-sectoral (e.g. education, health, social behaviour and cultural issues), but also inter-generational. Furthermore, the incorporation of indigenous knowledge into sustainability learning tends to be more cost-effective (since the usual classrooms structures are often not necessary) and provide a more fertile ground for the search for practical solutions to sustainability challenges $[8,12]$.

As Fig. 1 shows, learning on sustainable development may take many shapes and formats, and non-traditional approaches can play an important role in the process. The figure illustrates how the various modalities of non-conventional teaching approaches are related to the SDGs. One special feature is the flexibility, since learners can focus on one SDG only, or on a combined set of them.

But despite the advantages of non-traditional learning methods and tools, we still observe a fragmented approach towards them. Indeed, their implementation is characterised by various obstacles, from the lack of appropriately funded projects, to obstacles seen with respect to lack of experience and lack of training. These need to be further investigated and duly addressed, so as to allow a wider deployment of non-conventional learning approaches in both, formal and non-formal education contexts.

\section{Conclusions}

As this commentary has shown, learning on matters related to sustainable development in non-formal settings is not only multi-faced, but also has the ability to draw attention to social inequalities, while allowing for 
solutions to be discussed and developed. This is especially so in higher education, a sector which has a greater flexibility than in primary or secondary schools. Therefore, it may make sense to take better advantage of the opportunities they offer.

Combined, the various modalities of learning on sustainable development may specifically help in achieving the SDGs, especially those which target inequalities such as educational inequality (SDG4) and gender inequality (SDG5) [14]. More specifically, non-conventional learning spans across all age groups which helps in meeting a variety of learning needs. The widespread approach narrows the gap of educational and gender inequality and provides fair opportunities to all people.

\section{Acknowledgements}

Not applicable.

\section{Authors' contributions}

WLF performed as the major contributor in writing the manuscript. The author read and approved the final manuscript.

\section{Funding}

Open Access funding enabled and organized by Projekt DEAL.

Availability of data and materials

Not applicable.

\section{Declarations}

Ethics approval and consent to participate

Not applicable.

\section{Consent for publication}

Not applicable.

\section{Competing interests}

The author declares that there are no competing interests.

\section{Author details}

${ }^{1}$ European School of Sustainability Science and Research, Hamburg University of Applied Sciences, Hamburg, Germany. ${ }^{2}$ Department of Natural Sciences, Manchester Metropolitan University, Chester Street, Manchester M1 5GD, UK.

Received: 29 March 2021 Accepted: 2 July 2021

Published online: 21 August 2021

\section{References}

1. Balsiger J, Förster R, Mader C, Nagel U, Sironi H, Wilhelm S, Zimmermann AB (2017) Transformative learning and education for sustainable development. GAIA-Ecol Perspect Sci Soc 26(4):357-359. https://doi.org/ 10.14512/gaia.26.4.15

2. Bevan D, Kipka C (2012) Experiential learning and management education. J Manag Dev 31(3):193-197

3. English LM, Mayo P (2019) Lifelong learning challenges: responding to migration and the sustainable development goals. Int Rev Educ 65(2):213-231. https://doi.org/10.1007/s11159-018-9757-3

4. Grund J, Brock A (2020) Education for sustainable development in Germany: not just desired but also effective for transformative action. Sustainability 12(7):2838. https://doi.org/10.3390/su12072838

5. Haley D (2020) Unconventional educational approaches: an eco-pedagogy to address our transformative challenges. In: Leal Filho W, Azul AM, Brandli L, Özuyar PG, Wall T (eds) Quality education. Encyclopedia of the UN sustainable development goals. Springer, Cham. https://doi.org/10. 1007/978-3-319-95870-5_59

6. Kahn R (2010) Ecopedagogy: an introduction. Critical pedagogy, ecoliteracy, and planetary crisis: the ecopedagogy movement. Counterpoints, vol 359. Peter Lang, New York, pp 1-33

7. Leal Filho W, Mifsud M, Pace P (eds) (2018) Handbook of lifelong learning for sustainable development. Springer, Cham

8. Makondo CC, Thomas DS (2018) Climate change adaptation: linking indigenous knowledge with western science for effective adaptation. Environ Sci Policy 88:83-91. https://doi.org/10.1016/j.envsci.2018.06.014

9. Ouane A (2011) Evolution of and perspectives on lifelong learning. In: Yang J, Valdés-Cotera R (eds) Conceptual evolution and policy developments in lifelong learning. Hamburg, UNESCO Institute for Lifelong Learning, pp 24-39

10. Pettman JL (1996) Making the difference/teaching the international. In: Boud D, Miller N (eds) Working with experience: animating learning. Kogan Page, London

11. Sinakou E, Donche V, Boeve-de Pauw J, Van Petegem P (2019) Designing powerful learning environments in education for sustainable development: a conceptual framework. Sustainability 11(21):5994. https://doi. org/10.3390/su11215994

12. Šūmane S, Kunda I, Knickel K, Strauss A, Tisenkopfs T, des los Rios I et al (2018) Local and farmers' knowledge matters! How integrating informal and formal knowledge enhances sustainable and resilient agriculture. J Rural Stud 59:232-241. https://doi.org/10.1016/j.jurstud.2017.01.020

13. UNESCO (2017) Education for sustainable development goals: learning objectives. UNESCO, Paris

14. Vieira $D$ (2020) Lifelong learning and its importance in achieving the sustainable development goals. In: Leal Filho W, Azul AM, Brandl L, Özuyar PG, Wall T (eds) Quality education. Springer, Cham, pp 535-544

15. Webb S, Holford J, Hodge S, Milana M, Waller R (2019) Conceptualising lifelong learning for sustainable development and education 2030. Int J Lifelong Educ 38(3):237-240. https://doi.org/10.1080/02601370.2019. 1635353

\section{Publisher's Note}

Springer Nature remains neutral with regard to jurisdictional claims in published maps and institutional affiliations.

\section{Submit your manuscript to a SpringerOpen ${ }^{\odot}$ journal and benefit from:}

- Convenient online submission

- Rigorous peer review

- Open access: articles freely available online

- High visibility within the field

- Retaining the copyright to your article

Submit your next manuscript at $\boldsymbol{\nabla}$ springeropen.com 